Л.А.Шеремет,

кандидат філософських наук, доцент, докторант Інституту вищої освіти НАН Украӥни

\title{
ОСВІТНІЙ АСПЕКТ ВПЛИВУ СПОРТУ НА ДУХОВНУ КУЛЬТУРУ МОЛОДІ
}

Спорт, з огляду на місце та значення спортивної діяльності в сучасному суспільстві, постає як все більш визнана тематика досліджень у галузі соціальної філософії та філософії освіти, в тому числі й на вітчизняних теренах. Одними з перших у цьому напрямі були праці В.І.Столярова, який ще в 1980-90-ті роки досліджував сучасний спорт загалом. Окремо слід згадати соціально-філософський аналіз спорту, здійснений російським дослідником М.Ю.Мазовим, в працях якого йдеться про затвердження напряму філософських досліджень спорту в єдності особистісно-екзистенціального та соціально-комунікативного вимірів, про самоорганізацію його, спорту, як соціокультурного явища та перетворення його цінностей на неодмінні ознаки сучасного культурного буття. Варто назвати також таких українських дослідників, як С.М.Бацунов, В.С.Білогур, Л.М.Газнюк, В.Й.Григор'єв, М.М.Ібрагімов, С.В.Могільова та ін. Однак, незважаючи на значний внесок вчених у аналіз соціальної та філософської проблематики спорту, ще не склалося цілісного й теоретично опрацьованого погляду на актуалізацію можливостей людини в сучасному спорті як на складну, динамічно розвинуту, соціальну систему, що функціонує в суспільстві.

У наш час відбувається активний пошук нових форм і засобів гуманістичного виховання молоді, включаючи й студентську. Важливу роль при цьому відіграє спорт, який займає дедалі значніше місце в системі фізичного і духовного навчання студентської молоді, адже в ньому криються величезні можливості для позитивного впливу на весь комплекс фізичних і духовних здібностей людей.

Традиційні і сучасні соціально-філософські дослідження спорту показують, що суспільство постає одним із основних детермінантів його функціонування як соціально ціннісної системи, як соціокультурного явища. У свідомості молоді відбуваються зміни традиційних стереотипів і уявлень про цінності праці, професії, 
освіти, спорту. Відповідно трансформується соціальне самовизначення учнів і студентів внаслідок появи нових статусних цінностей (зокрема, фізичного здоров'я).

У формуванні орієнтації на здоровий спосіб життя спортом особливого значення набуває минулий досвід. Істотна роль його пояснюється тим, що він інтегрувався в свідомості, коли прагнення до фізичного здоров'я почало визначати одну з основних сфер діяльності. Оскільки культ фізичного здоров'я $є$ найважливішим засобом формування уявлення про себе, остільки на цій основі складається певне самооцінювання. Відповідно до неї формується і установка на фізичне самовдосконалення. Зрозуміло, уроки, почерпнуті з минулого досвіду, не фатально зумовлюють його орієнтацію на здоровий спосіб життя. У сферу того, що ми залічуємо до внутрішнього ядра стимулів, крім установок, сформованих раніше, включаються нові, що формуються під впливом суспільної, трудової діяльності і тих життєвих планів, які виношує людина.

Мотив заняття спортом, якщо його розглядати як «особистісний сенс», з одного боку, визначається суспільними вимогами до молодого покоління, його престижем у даному суспільстві і тим, як ці загальні вимоги позначаються на конкретній соціальній ситуації (зовнішні стимули). 3 іншого боку, мотивація зумовлена системою орієнтації, що склалися на попередньому етапі життя (внутрішні стимули). Іншими словами, установка на фізичне здоров'я визначається системою орієнтацій особистості, що формується під впливом конкретної соціальної ситуації. Оцінюючи соціальну та духовну ситуацію крізь призму своїх орієнтації і життєвих планів, людина виробляє провідний мотив «дії» (у нашому випадку - мотив фізичного, а отже, і психологічного здоров'я).

Системна криза, що зачепила соціальну структуру суспільства на початку перебудови та поглибилась у зв'язку з переходом до ринкової економіки, закономірно спричинила зміну соціальних орієнтирів, переоцінювання традиційних цінностей. Конкуренція на рівні масової свідомості радянських, національних і так званих західних цінностей не могла не вплинути на ціннісний світ молоді.

У процесі реалізації ціннісних орієнтації виявляється дія трьох факторів: 1) соціального середовища, в якому студенти та учні перебувають; 2) цілеспрямованого впливу суспільства, тобто виховання словом; 3) самих студентів та учнів, на яких всі ці дії спрямовано. 
Розгляд питання про вплив спорту на соціальний вигляд молоді дозволяє класифікувати соціальні функції спорту за їх соціально-педагогічними цілями:

1. Сфера спортивно-моторних цілей - потребує таких якостей, як спритність, витримка, сила, швидкість. Цілі спортивно-моторної активності завжди виступають у зв'язку з іншими установками, а не як самодостатні (наприклад, виховання сили духу, готовності до ризику, здатність до тривалих трудових зусиль, як розумових, так i фізичних, психологічна гнучкість та адаптивність, витримка і т.д.), які, своєю чергою, визначають соціальний образ молодої людини в iї навчальній, виробничій, психологічній діяльності.

2. Комплекс афективних цільових установок визначаються такими емоціями, як насолода і радість. Тут проявляється початкове значення поняття спорт («діспортаре», тобто «розвага», «задоволення»). Тож головна афективна цільова установка полягає в тому, щоб за допомогою спорту так задовольняти потребу в такій руховій активності, яка б приносила задоволення, радість, насолоду.

3. Сфера естетичних цілей визначається тим, що соціальна функція спорту спирається на традицію, яка сягає ідеального образу людини, створеного ще Платоном, образу, розвиненому Песталоцці в Новий час. Він не втратив свого значення й сьогодні. Грація та краса руху тіла розглядаються при цьому як головна естетична вимога. Значущість естетичної здорової зовнішності в ціннісній орієнтації істотно знижує можливість агресивної поведінки, вживання наркотиків, всього того, що негативно позначається на естетичних установках особистості.

4. Одну з головних ролей відіграють соціальні цілі. Відповідно, спорт є сферою для придбання такого соціального досвіду, який описується такими категоріями, як терпимість, готовність до співпраці, здатність допомогти ближньому, вміння поводитися в конфліктних ситуаціях і т.д.

Значення занять спортом виявляється і в тому, як вони сприяють зниженню рівня агресивності в суспільстві. У даному контексті може йтися про таку функцію спорту, як соціальна інтеграція. Вона може набувати різного значення - інтеграція різних соціальних верств суспільства; інтеграція різних поколінь; інтеграція різних культур; інтеграція сильних і слабких учнів та студентів.

5. Вплив спорту на соціальний і духовний образ молоді пов'я-

180 ISSN2078-8142Мультиверсум. Філософський альманах.-2015.-Випуск 3-4(141-142) 
заний із зміцненням моральності в характері людини. Як відмітна ознака спортивності розглядаються такі якості, як чесність, порядність, вміння з гідністю програвати. Саме етичний аспект цільових установок спортивної діяльності стає в наші дні все актуальнішим.

Із сказаного, можна дійти висновку, що, незважаючи на досить широкий діапазон проблематики - від моторики, афективних, естетичних до соціальних і етичних установок - все-таки існує перевага на тому чи іншому етапі розвитку соціуму, про який можна сказати, що він задається чинниками, які впливають на актуальність іiі ціннісного змісту. До таких чинників належать екологічні, моральноправові (наркоманія, злочинність, соціальна апатія й неадаптивність) та економічні (перехід до ринку, молодіжне безробіття та ін.).

Багато авторів, які вивчають ціннісні орієнтації молоді та їх зміни за останні десятиліття, стверджують про формування нової системи цінностей у широких мас. Це - орієнтація на якісні аспекти життя, заклопотаність проблемами охорони природи та навколишнього середовища, відмова від споживацького ставлення до навколишнього світу.

Слід також зазначити, що економічні труднощі, які звужують можливості задоволення матеріальних запитів, уповільнюють процес заміни старих «матеріалістичних» і технократичних цінностей новими - екологічними та антиспоживацькими.

Усі спроби вдосконалення освіти (в тому числі й початкової професійної) за останні десятиліття, а також зазначена тенденція до заміни ціннісних установок в масовій свідомості молоді засвідчують, що головний напрямок, який об'єктивно намітився й має перспективу - це звернення до людини, до теми іiі гідності, іiі фізичного та духовного благополуччя, які здійсненні, на наш погляд, через актуалізацію соціальної та духовної цінності фізичної культури і спорту. Саме на це мають бути спрямовані всі сфери суспільства, починаючи з освітньої, духовної і закінчуючи виробничою.

Реформування початкової та вищої професійної освіти є засобом формування культури майбутнього фахівця, а факторами розширення культурного простору виступають умови для фізичного та духовного розвитку учнівської молоді. У комплексі це сприяє реалізації міждисциплінарних зв'язків і усвідомлення значущості екологічного імперативу, такій корекції науково-технічного прогресу, завдяки якій основною цінністю стає людська особистість 3 
iї фізичним і духовним благополуччям.

Основою спортивної культури особистості учня й студента $є$ таке його позитивне ціннісне ставлення до спорту, в рамках якого цінності та норми культури, пов'язані зі спортом, стають надбанням власного внутрішнього світу індивідуума.

Позитивне ставлення учня й студента до спорту базується на певних вихідних знаннях, одержуваних у вищому навчальному закладі. При цьому позитивне оцінювання спорту та осмислення (обгрунтування) його залежить від освіти.

У наш час необхідно піднести на якісно новий, вищий рівень соціально необхідну освіту. Критерієм тут має бути, на нашу думку, перетворення соціально необхідної освіти в індивідуально необхідне. Так, прагнення студента до спортивних занять стає його внутрішньою потребою лише в тому разі, коли виробляються схильність (диспозиція, установка) щодо спорту, позитивна думку про спорт. Адже у значної частини випускників немає потреби в подальшому навчанні та творчому зростанні. Успіхи в навчанні перестали розглядати як засіб здобуття поваги серед друзів, досягнення службової кар'єри та ін.

Очевидно, що орієнтації можуть не збігатися зі структурою цінностей, що функціонує в суспільній свідомості. Іншими словами, для окремої людини може бути важливим і значимим зовсім не те, що є таким з точки зору суспільних інтересів і норм ціннісно орієнтованої суспільної свідомості, яка затвердилися в суспільстві. Саме через дану обставину важливими $є$ розбіжності між ціннісними орієнтаціями особистості та орієнтаціями їі на цінності, поширені або панівні в певному суспільстві. Орієнтація на цінності є певне ставлення індивіда до зовнішніх настанов, норм та звичаїв. Ціннісна орієнтація - внутрішній компонент його свідомості та самосвідомості.

За традиційним підходом до вивчення мотивів навчання молоді, зазвичай користуються наявними у психологів або соціологів праць 3 мотивації освіти. Поняття «мотиву» ми розглядаємо як усвідомлення сенсу навчання. Воно завжди пов'язане 3 потребами особистості, з виокремленням та оцінюванням нею явищ, що мають сенс для людини. Цим визначається відмінність між мотивом і стимулом.

Стимули виступають як сукупність зовнішніх спонукальних причин до дії. В значенні стимулів найзагальнішого і принципового порядку виступають фундаментальні соціальні фактори (насамперед 
суспільно-політична система суспільства), які створюють необхідні об'єктивні умови для навчання молоді. Однак існують і «специфічні» стимули, що характеризують певний вид виробничої діяльності, характер і стиль спілкування в колективі, сімейно-побутові відносини. Ця група умов не завжди виступає як «підтримуючі» стимули. Загальні й специфічні фактори можуть бути пов'язані так, що стимулююча роль одних немовби підкріплюється іншими. Між ними, однак, може бути й розрив, коли конкретні умови не підкріплюють загальну тенденцію, а суперечать їй. У цьому випадку їх стимулююча роль послаблюється. Але це не тягне за собою обов'язкового «згасання» мотиву. Адже мотив є результатом складного осмислювання вимог різного ступеня спільності.

Естетичні оцінки, судження і переживання не мають переважаючого впливу на внутрішній світ студента. Молодь переважно вельми скептично ставиться до бажання отримувати лише одну насолоду і задоволення від життя. Це засвідчує те, що вона не так прагне до насолод, як є незадоволеною існуючими формами творчої діяльності. Молодь хоче жити, і жити гідно. Поки соціальна політика не перемістить своїх акцентів (вона повинна перетворитися 3 політики «компенсації збитку» в політику попередження соціальних проблем), не виникне й гуманістично орієнтованої спортивної культури. Адже багато людей, за великим рахунком, намагаються виплеснути свою енергію в позитивне русло. Тому суспільство повинне приділяти величезну увагу формам спортивної діяльності, розвитку фізичної культури. Але це неможливо без підвищення престижу освіти.

Завдяки підтримці та впровадженню ефективної системи освіти розвинені країни отримують близько 40\% валового національного продукту. Найшвидше окупаються саме інвестиції в освіту: за даними американських фахівців, 1 долар, вкладений у витрати системи освіти, дає не менше 3-6 доларів прибутку.

Концепцію «попереджувальної соціальної політики» розвиває теорія модернізації, спрямована на пошуки шляхів побудови соціальної держави, а отже, і тієї соціальної політики, яка сприяє даному типу держав і суспільних відносин.

Серед критеріїв такого суспільства називають насамперед «досягнутий статус», що характеризує значну відкритість системи соціальної стратифікації. Іншими словами, це - створення ситуації 
«однакових можливостей», знищення та нівелювання різкого розмежування рівня й якості життя.

Створюється «досягнутий статус» внаслідок підвищення якості та, що важливо, доступності освіти, особливо вищої, через високоякісну і доступну охорону здоров'я, організацію нормальної життєдіяльності дітей та підлітків. Саме такий стан західні дослідники характеризують як етап вже пізнішої модернізації суспільства.

Для визначення ефективності соціальної політики застосовують два інтегрованих показника - рівень життя та якість життя.

Рівень життя - «соціально-економічна категорія, що виражає ступінь задоволення матеріальних і культурних потреб людей у забезпеченості споживчими благами, які характеризуються переважно кількісними показниками, абстрагованими від їх якісного значення (розмір оплати праці, прибуток, обсяг споживання благ i послуг, рівень споживання продовольчих і промислових товарів, тривалість робочого та вільного часу, житлові умови, рівень освіти, охорони здоров'я, культури тощо).

Якість життя - «соціологічна категорія, що виражає якість задоволення матеріальних і культурних потреб людей (в харчуванні, одязі, комфорті житла, охороні здоров'я, освіті, в змістовному спілкуванні, знаннях, творчій праці, а також рівень стресових станів, структуру розселення та ін.).

Дехто протиставляє якість та рівень життя, маючи на увазі під останнім певний життєвий стандарт, міру задоволення матеріальних і культурних потреб людей в плані їх забезпеченості споживчими благами. Як правило, останні характеризуються кількісними показниками, котрі часто не відображають якісного боку життя їх власників. Такого підходу дотримуються американські дослідники.

Автори подібного трактування якості життя вважають - чим вищий рівень життя і напруженіший життєвий ритм, тим нижча їх якість і навпаки. Розбіжності у визначенні поняття «якість життя» виникають 3 того факту, що воно визначається 3 різних боків: 3 фізичного, екологічного, економічного, медичного, соціологічного поглядів. Не претендуючи на повне перелічування всіх дефініцій «названого поняття», відзначимо лише ті, в яких підкреслюється зв'язок якості життя 3 якістю навколишнього середовища, тобто наголошується на збереженні в ній екологічної рівноваги. «Якість життя» залежить від рівня стресових ситуацій, щільності населення, 
якості продуктів харчування і ступеня забруднення навколишнього середовища.

Спираючись на існуючі дефініції якості життя, передусім ті, які визначають його з економічного погляду можна констатувати, що чим вищий рівень розвитку промисловості й національного доходу на душу населення, тим більші щільність населення та рівень забруднення навколишнього середовища, через що збільшується кількість стресових ситуацій, що знижують якість життя. А якість в цілому (або в середньому) в суспільстві підвищується тим активніше, чим більша кількість соціальних груп та індивідів можуть задовольнити відповідний обсяг своїх потреб [1, 92].

На жаль, сьогодні далеко не всі можуть задовольнити свої потреби в гідному, тобто в творчому та динамічному житті. Адже багато хто не має найнеобхіднішого - вільного часу, щоб займатися наукою, спортом, музикою, філософією і т.д. загалом життя сучасної людини спрямоване на боротьбу за виживання.

Виникає запитання: чому мислити, займатися спортом, наукою так нелегко? Крім обдарованості, людина, як відомо, має відзначатися особливою старанністю. Наукова, спортивна наполегливість частково споріднена з ретельністю в навчанні, тренуванні, але вимагає більших зусиль і наполегливості.

Водночас наукова старанність відрізняється від спортивної, адже стикається 3 нею в наочному зображенні і розмірному оформленні (кращі фігури атлетів відображені образно). Ці форми дозволяють грати, а займатися наукою - ні. Тут потрібні свої власні зусилля. При цьому не відразу з'ясується, що така старанність необхідна, аби подолати виниклі перешкоди. Разом $з$ тим слід підкреслити, що спорт, музика, інші сфери мистецтва розпалюють занепокоєння суб'єкта, викликають стан незадоволеності кожною миттю. Крім того, розвиток спорту дає змогу суспільству перенестися в простір Ренесансу, звідки вийшли буржуазна емансипація та легенди про Фауста, що нагадує про Парацельса і Кеплера, які «бажали мати орлині крила, щоб досліджувати таємниці земні й небесні» $[3,102]$.

Рух, який ми сьогодні спостерігаємо в спорті, має багато суперечностей. Він здійснюється завдяки незадоволеності особистості та ситуаціями, що весь час стають кризовими. Протиріччя між спортивним життям і об'єктивністю є головним, особливо, коли ми

ISSN2078-8142 Мультиверсум. Філософський альманах.-2015.-Випуск 3-4(141-142) 185 
хочемо проникнути в суть духовного життя суспільства. Адже спортивний дух, який постійно заперечує досягнуте, повністю входить у реальний життєвий процес і покликаний за допомогою заперечення діяти, викликати у людей духовну стурбованість. Причому таким чином, що заперечення змушує битися саме суспільне життя. Як бачимо, спорт підтримує пульс здатності до зміни, до духовної самореалізації суб'єктів.

Особливо це стосується такого суб'єкта, як студентська молодь. Ïї духовна культура в цілому являє собою систему, що саморозвивається. Однак конкретним джерелом цього розвитку виступають різні сфери життєдіяльності юнаків і дівчат. Спортивна діяльність ніколи не зможе ціннісно орієнтувати особистість, якщо не буде включеною в більш широкий життєвий контекст. «Духовна культура молоді, - пише М.А.Багаутдинов, - корениться в їі ціннісних орієнтаціях. Цінності та ціннісні орієнтації становлять внутрішнє джерело й «ядро» духовної культури. Найвищий рівень в системі цінностей молоді займають моральні й естетичні цінності. Саме вони надають ціннісним орієнтаціям системну якість, визначають їх єдність і загальну спрямованість. Тому дані цінності мають особливу значимість у формуванні духовної культури.

Стрижневим завданням духовного виховання має стати формування та розвиток у молодої людині духовно-діяльнісного начала, прагнення до загальнолюдських цінностей, до самореалізації. Формування та розвиток у молоді прагнення до духовної самореалізації має бути визнано стрижневий завданням духовного виховання, всього процесу формування та розвитку духовної культури молоді» [2, 105].

Дослідження впливу спорту на духовно-екзистенційну культуру молоді показують, що молоді люди цінують спорт насамперед за ті властивості, вироблення яких він сприяє. Переважна кількість студентів пов'язують спорт з такими якостями, як вихованість, почуття обов'язку, чесність, щирість.

Формуючи філософську позицію особистості щодо фізичної культури, необхідно враховувати, що духовний спосіб життя має бути добровільно обраний особистістю. Молода людина, яка обрала напрям своєї діяльності формування потенціалу фізичної культури, спирається на такі установки під час активного вибору: 1) все, що відбувається зі мною, має причину в мені, 2) я - господар свого світу; 3) я певною мірою можу керувати своїми життєпроявами. А це вже 
актуальний аспект впливу духовності на фізичну культуру і спорт.

Щодо механізму особистісного розвитку, слід підкреслити в ньому аспект скритності, «інтимності». Очевидно, потрібно відрізняти той дійсний зміст внутрішньої роботи людини від того, як вона цю «роботу» презентує іншому. У цьому сенсі соціалізація грунтується на допомозі маленькій людині в подоланні й знятті внутрішнього конфлікту.

Допускаючи в свій внутрішній світ педагога, вихованець в будь-якому разі прагне показати цей світ таким, яким би він хотів, щоб його бачили. У цій побудові зовнішнього презентанта свого образу, у виробленні особистого «іміджу» теж стоїть один із аспектів механізму розвитку індивіда. Адже людина, яка не любить, коли до неї «лізуть у душу», водночас мріє бути зрозумілою, почутою, причому «правильно» (з іiі погляду).

Отже, «інтимність» особистісного простору виконує істотну функцію в цілісному механізмі особистісного розвитку. Ця функція полягає у своєрідному «захисті» цілісності та індивідуальності внутрішнього світу людини. Саме інтимність процесу особистісних новоутворень зумовлює те, що досвід індивіда є продуктом його саморозвитку, а не зовнішнього впливу. Функція автономності як невід'ємна властивість особистості дає змогу їй протистояти тотальній «колективності», «державності», загальній «ідеологічності».

Розвиток особистості передбачає іï «експансію» в інші світи, персоніфікацію, продовження себе в іншому «Я», а також формування потреби отримати визнання свого соціального оточення. Це свого роду становлення і «вправа» здатності бути особистістю. «Особистість не існує поза системою своїх виборів, або конституюється, створюється. Тому вона - завжди проект ... лише певна можливість, яка не завжди буває реалізована» $[4,24]$.

Проективність, здатність здійснювати усвідомлений вибір показник духовного здоров'я особистості. Особливо це стосується студентів. Збереження їхнього духовного і фізичного здоров'я має своєю передумовою певний компроміс між обов'язковістю вирішення освітніх завдань і необхідністю відтворення при цьому фізичних і душевних сил, яке багато в чому залежить від форм $\mathrm{i}$ методів навчального процесу, психологічного клімату в навчальному закладі, від організації спеціалізованої системи формування, збереження та відтворення здоров'я. 


\section{ЛIТЕРАТУРА}

1. Азаматов Д.М., Мазов Н.Ю. Система образования в трансформирующемся обществе: проблемы, противоречия, перспективы. - Уфа, 2004. - 116 с.

2. Багаутдинов А.М. Методология исследования духовной культуры молодёжи. - Уфа, 2005. - С. 105.

3. Блох Э. Тюбингенгское введение в философию. - Екатеринбург, 1997. - 394 с.

4. Шевеленкова Т.Д. Исследование личностного способа существования человека в современном мире // Психология личности в условиях социальных изменений. - М., 1993. - С.21-37.

Шеремет Л. А. Освітній аспект впливу спорту на духовну культуру молодi.

У статті аналізується вплив спорту на духовно-екзистенційну культуру молоді та на цій основі досліджується освітній аспект спорту. Адже спорт підтримує здатність до зміни, до духовної самореалізації суб' єктів. Особливо це стосується такого суб'єкта, як учнівська та студентська молодь. Її духовна культура в цілому являє собою систему, що саморозвивається. Спортивна діяльність ціннісно орієнтує особистість, будучи включеною в ширший життєвий контекст.

Збереження духовного і фізичного здоров'я має своєю передумовою певний компроміс між обов'язковістю розв'язання освітніх завдань і необхідністю збереження та відтворення при цьому фізичного й душевного здоров'я. А саме збереження здоров'я молоді багато в чому залежить від форм і методів навчального процесу, психологічного клімату в навчальному закладі і від організації спеціалізованої системи його (здоров'я) формування та відтворення.

Ключові слова: спорт, культура, гуманістичне виховання, освіта, мотив, иіннісний світ.

Шеремет Л.А. Образовательный аспект влияния спорта на духовную культуру молодежи.

В статье анализируется влияние спорта на духовно-экзистенциальную культуру молодёжи и на этой основе исследуется образовательный аспект спорта. Ведь спорт поддерживает пульс способности к изменению, к духовной самореализации субъектов. Особенно это касается такого субъекта, как учащаяся и студенческая молодёжь. Её духовная культура в целом представляет собой саморазвивающуюся систему. Спортивная деятельность ценностно ориентирует личность, будучи включённой в более широкий жизненный контекст.

Сбережение духовного и физического здоровья предполагает опре-

188 ISSN2078-8142Мультиверсум. Філософський альманах.-2015.-Випуск 3-4(141-142) 
делённый компромисс между обязательностью решения образовательных задач и необходимостью сохранения и воспроизводства при этом физического и душевного здоровья. Сохранение здоровья молодёжи во многом зависит от форм и методов учебного процесса, психологического климата в учебном заведении и от организации специализированной системы формирования, сохранения и воспроизводства здоровья.

Ключевые слова: спорт, культура, гуманистическое воспитание, образование, мотив, ценносный мир.

Sheremet L.A. The educational aspect of the impact of sport on the spiritual culture of the youth.

This article analyzes the impact of sport on the spiritual and existential culture of youth and on this basis explores the educational aspect of sport. Sport supports the ability to change the pulse, the spiritual fulfillment of subjects. This is especially true of the subject as a student and the student youth. The development of its spiritual culture in general, is a self-developing system. Sporting activities valuable reference person proving included in a broader life context.

Preservation of spiritual and physical health involves a certain compromise between the binding decision of educational problems and the need for preservation and reproduction with the physical and mental health. Maintaining the health of pupils and students largely depends on the forms and methods of educational process, the psychological climate in the school and the organization of a specialized system of formation, preservation and reproduction health.

Key words: sport, culture, humanistic education, education, motive, the value world. 